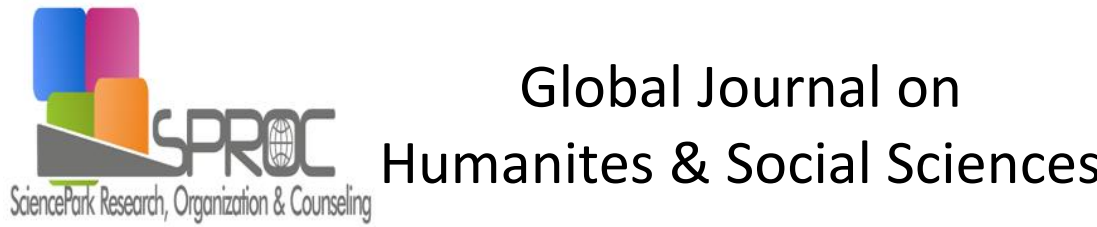

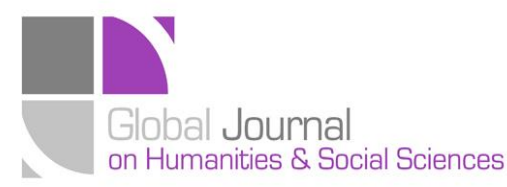

Issue 4 (2016) 857-864

Selected Paper of 4rd World Congress of Administrative and Political Sciences, (APDOL-2015)

26-28 November 2015, Rome, Italy

\section{Security threats and challenges in the post-soviet Central Asia: religion-based extremism on case study of ISIS}

\author{
Fatima Kukeyeva*, IR Department, al-Farabi Kazakh National University, Karasai Batyr 95, Almaty, 050000, \\ Kazakhstan \\ Leila Delovarova, IR Department, al-Farabi Kazakh National University, Karasai Batyr 95, Almaty, 050000, \\ Kazakhstan \\ Tolganay Ormysheva, IR Department, al-Farabi Kazakh National University, Karasai Batyr 95, Almaty, 050000, \\ Kazakhstan \\ Yermek Chukubayev, IR Department, al-Farabi Kazakh National University, Karasai Batyr 95, Almaty, 050000, \\ Kazakhstan
}

\section{Suggested Citation:}

Kukeyeva, F., Delovarova, L., Ormysheva, T. \& Chukubayev, Y. (2016). Security threats and challenges in the post-soviet Central Asia: religion-based extremism on case study of ISIS,

[Online]. 04, pp 857-864. Available from: http://sproc.org/ojs/index.php/pntsbs

Received May 10, 2015; revised August 16, 2015; accepted September 16, 2015.

Selection and peer review under responsibility of Prof. Dr. Andreea lluzia IACOB

(C)2016 SciencePark Research, Organization \& Counseling. All rights reserved.

\begin{abstract}
Nowadays the post-Soviet Central Asian countries face a broad range of security challenges and threats. Some of them are systemic in nature, while others occur sporadically. Many challenges and threats are coming from the outside the region, but the countries' internal situation and background including historical, economic, social and political aspects. The reaction in the countries on religious-based radicalism and movements like ISIS is an ambiguous. The range and level of the threats and challenges depends on various reasons and different in all Central Asian countries. But the case of ISIS is very unprecedented and needs to be under the special analysis through the political and socio-economic dimension in all states. The different ways of development chosen by Kazakhstan, Kyrgyzstan, Tajikistan, Turkmenistan and Uzbekistan and different background including borders, political systems, the role of religion and social stability defines the reflection to the threat in different way. Tajilistan and Uzbekistan are in high risk zone. The existing regional and extra regional organizations as CSTO and SCO are important in terms of security strengthening in Central Asia. Analyzing the general social, economic and religion climate picture in terms of absorbing or reflecting religious based extremism and ISIS the real power to stop it can be both effective inter-governmental cooperation and coordination with strong civil society support.
\end{abstract}

Keywords: security, Central Asia, extremism, ISIS;

* ADDRESS FOR CORRESPONDENCE: Fatima Kukeyeva, IR Department, al-Farabi Kazakh National University, Karasai Batyr 95, Almaty, 050000, Kazakhstan. E-mail address: fturar@mail.ru 


\section{Methodology}

Methodological basis of the paper consists of the elements of international relations theories to explain the possible challenges and risks coming from the ISIS for Central Asian political regimes.

The theories of realism and relative deprivation were used to analyze considering issues. These theories are helpful to explain why people would display a tendency towards violent action such as overthrowing a regime or engaging in mass violence at a particular time and by religious reasons, and the governments' response to keep the political regime. The paper employs realist reasoning to explain the effects of changing reality on the ground on the rationales of states to cooperate.

The article is also based on the theories considering and explaining the concept of the modern "security". Today "security" as a political value has no independent meaning and is related to individual or societal value systems. So, from the realist perspective, objective security is achieved by managing threats, challenges and risks by the state or by the regional or global international organizations. From the social constructivism perspective, security should be seen not only from the standpoint of the state, but also human security, as a result of the social and political interaction process, and the influence of socio-economic conditions, cultural and religious traditions.

It is obvious that security in Central Asia depends on the internal stability of the states and external influences. Religious-oriented extremism and as a result, the growing threat of terrorism is a reality to all five Central Asian countries: Kazakhstan, Kyrgyzstan, Tajikistan, Turkmenistan and Uzbekistan.

Central Asian countries are on the influence of such centers of the terrorist activity as Afghanistan, Xinjiang and Kashmir. According to the experts, after withdrawal of allied forces from Afghanistan the threat of destabilization of the political situation will increase in the entire region of Central Asia.

Experts and the media debate the issue of political Islam as a threat to political regimes of the regional states. The terms extremism, radicalism, terrorism and fundamentalism are also used by the Central Asian leaders to describe the danger for stability.

Predominantly Muslim population, geopolitical location, the suppression of religious activity by the governments has created a favorable space for Islamist militancy in regional states. Contemporary situation demonstrated the religious-oriented extremist groups grew stronger, as the ability of Central Asian regimes to control the situation weakened. As a result, some Islamist groups began to call for a regional caliphate.

\section{The "Islamic State" growing threat to Central Asia}

Recently, Islamic State of Iraq and the Levant (ISIS) representatives declared that one of their organization's tasks is the destabilization of the situation in the Muslim countries of Central Asia as well as in Russia. Information about participation of CA countries' citizens in the ISIS activity complicated the situation. In September 2014 the organization clearly identify forward-looking strategic direction - "Movarounnakhr" (the historical name of Central Asia) (Uzbekistan news 2014).

The "Islamic state" leaders announced their plans to advance to the East and to conquer the immense territories including Central Asia, with the establishment of the Sharia law. This fact forced the Central Asian leaders to worry even more and to try to find an answer to the looming threat. Therefore one of the main challenges which all states of the region should face practically in the nearest future is the growth of religious extremism and threat of terrorist groups' penetration into Central Asian countries.

Militants with the support of the regional extremist religious groups are not simply increased the risks to regional security, but also create a real threat to the political regimes in Central Asia. The problem is actualized by the processes occurring in the political life of the countries like the 
Kukeyeva, F., Delovarova, L., Ormysheva, T. \& Chukubayev, Y. (2016). Security threats and challenges in the post-soviet Central Asia: religionbased extremism on case study of ISIS,

http://sproc.org/ojs/index.php/pntsbs

presidential elections. Political regimes stability depends on the confidence of citizens, the electorate. The society radicalization is a reaction to the low socio-economic living standard, uneven economic development of regions of the same country, the lack of state ideology, corruption in the government, etc.

These and other factors lead to increase of the protest potential, which is often expressed in social unrest. Today, the situation in the region is exacerbated by the impending of the new wave of economic crisis and as a consequence of the growing threat of instability.

Central Asian analysts and politicians argue: Does "Islamic State" pose a real threat to the Central Asian political regimes? What responses are taken by Central Asian states, and how effective are they? Experts agree that in the foreseeable future the "Islamic State" may pose a threat to the political stability of Central Asian countries, but their opinions on this issue are divided into two groups.

The main arguments of "optimists" are based on the following facts: the geographical distance between the "Islamic State" location and CA region; the conflict absence between Sunnis and Shiites in Central Asian countries; internal contradictions in the organization; cultural, mental and political differences of Central Asian and the Middle East countries (Malashenko \& Ilkhomov, 2014).

"Alarmists" and "pessimists" indicate the seriousness of the situation. The experience which is saved up by Islamic State terrorists in Iraq, Syria, Jordan can use for attacks to Central Asian states. There is a potential risk due to the inability to determine the true force supporting this organization and its real opportunities (Report-IA 2015). Concentration of militants on the Afghan-Turkmen and Afghan-Tajik borders is evidence that the "Islamic state" considers Central Asia as a priority area of its interests. (Day.az 2015; Newskaz.ru 2015; TASS 2015).

Participation of Kazakhstan, Kyrgyzstan, Tajikistan and Turkmenistan citizens in the ISIS activity aggravates the situation with regional security. According to the special services info, after homecoming militants carry out a role of recruiters of new soldiers for the "Islamic State". (Already there is evidence of militants of all stripes activation in Afghanistan in the Tajik directions. There are about 4000- 4,500 "Jihad" soldiers (Bahrom, 2015).

Tajikistan is considered as the weakest link of Central Asia. Firstly, the situation in Tajikistan is influenced by its direct proximity to Afghanistan. The length of the Tajik-Afghan border is $1,344 \mathrm{~km}$, most of which passes through inaccessible areas by high mountains. As the allied troops withdrawal from Afghanistan, the operational situation in the previously peaceful provinces of the country deteriorates. Thus, according to information Muhammad Umar Kunduz Safi, Governor of Afghan Province adjoining on Tajikistan, the members of the "Islamic State" is activated in Badakhshan, Takhar, Baghlan, Faryab provinces that border with Tajikistan and Turkmenistan. This leads to_increase the total number of militants from various groups on the Tajik-Afghan border (Beresnev, 2015). Secondly, the continued Tajik-Uzbek conflict affects the situation with security. The main reason of the conflict is the construction of hydroelectric power station in Tajikistan that according to Uzbekistan, can intercept irrigation water. It causes not only collisions on inter-ethnic clashes, but also because of water distribution.

Thirdly, in the country there is a strong Islamic opposition. The Party of Islamic Revival of Tajikistan (IRPT) enjoys authority, both in the republic, and in the Tajik Diasporas abroad. IRPT is party of moderate persuasion but if it is excluded from participation in the political life of the country, the party leaders will turn towards aggression and radical politics.

Fourthly, more than 2,000 Tajiks are fighting on the side of the "Islamic State" now. (Asia Plus 2015). The reason that the Tajiks fight for ISIS explained as socio-economic and religious-ideological reasons According to Abdullo Muhakkik, an expert on religion in Tajikistan, advocacy of ideas of Salafis 
Kukeyeva, F., Delovarova, L., Ormysheva, T. \& Chukubayev, Y. (2016). Security threats and challenges in the post-soviet Central Asia: religionbased extremism on case study of ISIS,

[Online]. 04, pp 857-864. Available from:

http://sproc.org/ojs/index.php/pntsbs

among Muslims of the country attracts youth to fight in the ranks of the "Islamic state" organization.(Islam News 2015).

Not only the Tajik-Afghan, but also the Turkmen-Afghan border is one of the possible impact points for destabilization the situation in Central Asia. The border opens the gate to the western regions of Kazakhstan with the growing jihads activity.

According Turkmen special services, the number of the "Islamic State" military units has been increased in the territory near Afghanistan. Turkmenistan is the most vulnerable link in the security system of Eurasia. Turkmen 750-kilometer section of border is not protected by natural barriers as a Panj river in Tajikistan and Pamir mountains.

For this reason Turkmenistan prepares for a long war against the "Islamic State". Defense Ministry of the Republic already carries out mobilization of the military in reserve. In November 2014 the new changes were added to the law "On Military Duty and Military Service in Turkmenistan". Ashgabat tries to increase the rates of mobilization for reflection of future attack from the "Islamic State" and "Taliban" on the border with the Afghan province of Jowzjan. The ditches of 6 meters in depth and the columns of 2 meters high stretched barbed wire between them are created in the this territory. (Rossiya 2015).

According Shohrat Kadyrov, the well-known researcher of the Oriental Studies Institute, "the neutral status of the Republic prevents the full protection of the Turkmen territory».( Panfilova, 2015).

The point is the threats and challenges of religious-oriented extremism require joint action from regional states. It will be difficult to Turkmen policymakers to build a coherent policy together with Central Asian neighbors in the framework of neutrality. It is doubtful that in these conditions Ashgabat will keep the ability to continue the policy of not joining the military-political alliances.

All kinds of Islam are presented In Kyrgyzstan, including a radical one whose goal is to promote ultimate Islamic values. Kyrgyzstan has already endured two color revolutions. The third time religious -based extremism factor could play key role with all its consequences. ISIS considers Kyrgyzstan as a gateway to the Ferghana Valley and Uzbekistan. This fact explains the "Islamic state" leaders' decision to allocate about 70 million USD to destabilize the situation in Central Asia and particularly in southern Kyrgyzstan. (AKIpress 2015) Socio-economic situation in the country creates favorable conditions for recruiters: the rise of unemployment among young people, the clashes between Uzbeks and Kyrgyz, the high level of radicalism in Fergana Valley. The ranks of the militants is replenished by natives from Isfara and the Fergana Valley - Namangan, Osh, Andijan, Aravan (Ibrayev 2014). Liberal legislation and freedom of speech in Kyrgyzstan also create the basis for the ISIS ideas propagation (Bektayev, 2015). No wonder the country is called the "island of democracy". In Kyrgyzstan, more than three thousand non-governmental organizations that can make a destructive element in the situation with religious extremism.

The recruiters conduct active work on all Osh area. The public opinion is extremely concerned about fact that even young children are involved in their orbit. Not only the poor people, but also the middle class representatives, who join "Islamic State" for ideological reasons, are the target of ISIS. The promotion of the organization ideas and attraction of the new members is mainly made through the Internet. In practice the "Islamic State" finds its members among people who were deported from Russia and Turkey for violating immigration laws. 
Bishkek today is not so much concerned about the threat of terrorism as a problem of islamization of the population, which risks taking the radical forms. In addition, Kyrgyzstan has the weakest power structures in all Central Asia, and the country is virtually defenseless in the face of extremists.

In the region today is quite complicated the situation around Uzbekistan. Approaching a new wave of economic crisis; growing threat of instability aggravated by the coalition forces withdrawal from Afghanistan; increasing and activation of religious extremist groups as Islamic Movement of Uzbekistan (IMU) and "Akramiya" which were founded in Uzbekistan.

In September, 2014 Usman Ghazi, the leader of the IMU announced his organization has joined the group ISIS. The IMU joining to the "Islamic State" raise the risks for the political regime of the country. They call for the overthrow of the Karimov's regime and the establishment of an Islamic caliphate in Central Asia.

According to the media in November 2014 the first trial of the ISIS recruiter who was caught in Uzbekistan started in Karshi, Kashkadarya region. Accused Nadir Zhavliev told to TV channel "Uzbekistan", that as a member of the "Islamic state" he participated in the military operations in Syria and Iraq. He was sent to Uzbekistan to recruit new organization supporters. Zhavliev illegally crossed the Uzbek - Kyrgyz border, but he was arrested in Fergana region. During the arrest videos with the calling to overthrow secular power were confiscated (Yuldasheva, 2015). Growing religious fundamentalism is coupled with the citizens' protest sentiment creates a breeding ground for political Islam in the country. Uzbekistan is a state with a very large gap between the rich and the poor. The idea of social justice is concentrated in political Islam, which is a real challenge for power. Uzbek political regime has all chances to face the danger of consolidation the social justice ideas with Islamic tradition.

But Uzbekistan differs from Tajikistan and Kyrgyzstan by its strong vertical of power, allowing restraining extremist movements and even religious moods among citizens. Restrictions on religion, strict control over the mosques, discrimination of the disagreeable mullahs, oppositional groups and organizations - all this - the current realities of Uzbekistan

The Mahalia institution is another instrument for control, using by Uzbek government. It now operates partly as part of the state mechanism of social regulator. Mahalia serves as a bridge between the government and communities, creating a balance of trust. Violation of this balance is fraught with the social unrest and political instability provoked by religious extremist organizations (Musurmsnkulov, 2013). Therefore, for the Karimov's regime is important to prevent the spread of ideas and influence of organizations as the ISIS in the Uzbek community.

President Karimov uses the clashes with Taliban on the Afghan-Uzbek border as an argument to justify the anti-terrorism policy tightening. "We have a strong assumption that the "Islamic State" participants' activity arrested in Uzbekistan last year, was not limited by recruitment. ISIS members prepared a series of terrorist attacks in spring, 2015 in Uzbekistan. That is why we are strengthening measures to protect our borders, "- said Alisher Khamdanov officer of Uzbek National Security Service

(CentralAsiaOnline 2015)

Until recently Republic of Kazakhstan (RK) was considered as the territory of stability, religious moderation and tolerance. Kazakhstani officials always emphasized the lack of the basis for religious extremism in the country. 
However, since the second half of the 2000s series of terrorist attacks evidenced that Islamist underground has appeared in the country and radical Islam grows steadily. As a result of terrorist attacks in 2011-2012 70 people were killed (6 civilians, 13 security forces, 51 terrorists) (Kalishevsky, 2014). During these actions proved the new Kazakh Islamic extremist groups "Soldiers of the Caliphate", "Defenders of religion". The Committee of National Security (CNS) of Kazakhstan in 2014 reported that in the ranks of ISIS 300 citizens of RK are at war (Nur.kz 2014).

Therefore, Kazakhstan should not ignore the threat to the "Islamic State". Firstly, Central Asia is located in a close proximity to the countries with the strong position of radical Islam - Afghanistan, Pakistan, Uzbekistan and others. The transparency of the state border, the security services incompetence, the arbitrariness of bureaucrats. All this factors facilitate the foreign Islamists penetration in Kazakhstan

Secondly, there are prerequisites in the state for formation of one more base for the Sunni radicals near Shiite Iran. Social and economic stratification, the growing number of unemployed young people not integrated into society, high level corruption in the government, search for a new ideology, religious illiteracy are the main factors for the spread of the radical ideas.

Third, the situation could be used by non-regional actors to establish control over natural recourses and raise geopolitical competition within the "Great Game".

Fourth, considering social and economic and military-political weakness of the majority Central Asian states, Kazakhstan shouldn't expect that the southern neighbors will be able to hold back the forces of the "Islamic State" and to act as a buffer.

Thus over the past five years, Kazakhstan has gone from a country where practically no threat to religious - based extremism and terrorism, to create a local radical groups and the participation of citizens in terrorist attacks inside the country and abroad.

As Kazakhstan has a strong vertical of power, the state responds to the threat mainly by force. Power structures activity is dictated by the desire to maximize control over the religious citizens. In many cases this indicates absence of adequate assessment of the challenge.

The "Islamic States" threat revealed another problem as a lack of effective work of official religious representatives with the population of the country. In practice the promotion of the radical ideas and recruitment of the young people occurs in mosques. According experts, the_Spiritual Administration of Muslims of Kazakhstan (SAMK) is a typical bureaucratic organization and it is not able to control the processes taking place in the Muslim community and effectively counteract Islamic extremism. (Kalishevsky, 2014)

In spite of the fact that Central Asian countries differ from each other in many ways and the level of threat for each state varies, today the threat of religion-based extremism represented by the "Islamic State" organization is a reality for all five political regimes. There is a risk of transition from recruitment to terrorist attacks. The regional countries with low economic indicators and large protest potential as Kyrgyzstan and Tajikistan, are in the highest risk to become a targeted for the ISIS.

In a difficult situation is Turkmenistan, declaring its neutrality status in a need for joint action against the threat of religious extremism.

Strong vertical of power in Uzbekistan and Kazakhstan is not a panacea for the recruitment of citizens into the ranks of the ISIS.

The society radicalization is a direct threat for Central Asia's secular regimes. The people seeking justice, socially marginalized segments of the population join the ranks of the extremist movements.

In Kyrgyzstan and Tajikistan about one third of GDP consists of migrant remittances. Change of the situation for the worse can push the unemployed into the ranks of the jihadists. 
Kukeyeva, F., Delovarova, L., Ormysheva, T. \& Chukubayev, Y. (2016). Security threats and challenges in the post-soviet Central Asia: religionbased extremism on case study of ISIS,

http://sproc.org/ojs/index.php/pntsbs

Social protest in the form of religious extremist movement is not always correlated with poverty. Among the participants there are both rich and intellectuals. Point is that all of them attracted by the idea of social justice, which can not provide the existing political regimes.

It has to be clearly understood that the gravest threat to Central Asia's secular regimes comes from within, from their own populations. External factors come second (Malashenko, 2015). If the power is not able to consolidate the society and people's expectations do not meet the real life it creates the ideal conditions for political Islam appearance. Against this backdrop, Islam in full accordance with its spiritual tradition offers the different but a quick way out of this situation.

Another contentious issue is the ability of the countries of Central Asia independently to resist to this threat.

According experts, the armies of Central Asian countries will not be able independently confront ISIS. The states have no appropriate military capabilities and the consolidation of nations needed for conducting antiterrorist operations. Despite the fact that the Uzbek and Tajik armies have some experience to conduct hostilities they can resist the minor challenges, but not the systematic terrorist attacks like in the Middle East. So they will be forced help from other countries. Firs of all, from Russia (Malashenko, 2015).

During Putin's visit to Uzbekistan, in December 2015, the President Islam Karimov asked his Russian partner to help his country to counter the threats of militant Islam. (Sorbello, 2015) Within the framework of the Kyrgyz-Russian military cooperation Bishkek received military and armament equipment on the amount of 1.2 billion dollars. 200 million dollars will be spent on the military modernization of Tajikistan. Turkmenistan has seriously increased contacts and negotiations with Russia on many issues, including political. In the last CIS summit in Minsk Turkmen President Berdimuhamedov noted that the CIS potential is very important for maintaining regional security. Kazakhstan is rapidly modernizing its army, equipping it with modern weapons (Bekov, 2014).

\section{Conclusion}

Geopolitical and geo-economic role of post-Soviet Central Asia subjects it on a constant risk of various challenges and threats from different international actors. Despite the fact that all countries follow a different path of development, some of the challenges are equally dangerous for every state. The threat posed by ISIS is a proper case to be studied. The case is very relevant and able to destabilize the political situation in Central Asian countries; it requires new methods and tools to promote the interests of the civil society. Geo-economic paradigm raises the question of the new instruments and mechanisms to meet the challenges, to prevent threats and manage risks with combined genesis. Today the states to a greater extent have to take into consideration the regional and the global processes.

The existing regional and extra regional structures in Central Asia like CSTO and SCO could seriously contribute not only in military sense but also in terms of information exchange. The security system itself requires the development of multi-vector security approach.

As one of the tools offered could be the spreading of religious and ideological education in high schools based on secular approach. It is also very important to establish a constructive dialogue between citizens, representatives of the official representatives of Islamic religion and the countries. Within the dialog de-radicalization/ rehabilitative programs could be developed to help ISIS militants returned home. Political system modernization and democratization is an essential factor of the society stabilization.

The religious-based Extremism presented by the "Islamic State" and the calls for integration design for the strengthening and consolidation of the regional geopolitical and then geo-economic space, which would develop a common effective strategy for the sustainable development of the region. 
Kukeyeva, F., Delovarova, L., Ormysheva, T. \& Chukubayev, Y. (2016). Security threats and challenges in the post-soviet Central Asia: religionbased extremism on case study of ISIS, [Online]. 04, pp 857-864. Available from:

http://sproc.org/ojs/index.php/pntsbs

\section{References}

AKIpress (2015). ISIS possibly allocates \$70 million to destabilize situation in CA. Retrieved January 20, 2015 from http://www.akipress.com/news:554434/

Asia Plus (2015) Nusrat Nazarov says that more than 2,000 Tajiks are at war for ISIL. Retrieved January 29,2015 from http://news.tj/ru/news/nusrat-nazarov-utverzhdaet-chto-bolee-2000-tadzhikov-voyuyut-za-igil

Bahrom, N. (2015) Afghan militants mass along Tajik frontier, Central Asia on line Retrieved January 16.2015 from: http://centralasiaonline.com/en GB/articles/caii/features/main/2015/01/21/feature-01

Bekov, I. (2014) Greetings from the ISIS: In Central Asia there is a threat of the beginning of military operations. Retrieved December 17, 2014 from: 65info.kz/2014/12/

Bektayev, V. (2015) Expert: "Bishkek can become the capital of ISIS in Central Asia" Retrieved February 4, 2015 from: http://www.news-asia.ru/view/ks/interview/7891

Beresnev, O. (2015) Enemy at Gate: "Islamic state" on approaches to Russia. Retrieved February 18, 2015 from http://m.ria.ru/cj analytics/20150206/1046330202.html?rubric=cj

CentralAsiaOnline (2015) Fighters of IGIL planned acts of terrorism in Uzbekistan, declare the authorities.

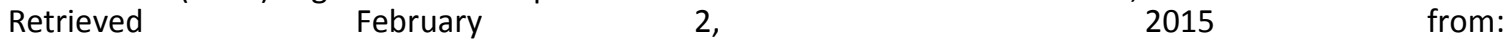
http://centralasiaonline.com/ru/articles/caii/features/main/2015/02/02/feature

Day.az (2015) The "Islamic State" threaten Turkmenistan borders. Turkmenistan announced the mobilization of reservists. Retrieved from http://news.day.az/world/557173.html Accessed February 18. 2015

Ibrayev, Z. (2014) Kyrgyz company in ISIS. Retrieved December 15, 2014from http://www.knews.kg/analitika/58173 kyirgyizskaya rota $\mathrm{v}$ igi

Islam News (2015). In social networks the information about the death of one of the leaders of the Tajik militants in Syria has appeared (2015) Retrieved February 12, 2015 from: http://islamnews.tj/tajikistan/979sirii.html

Kalishevsky, M. (2014) Kazakhstan on its way to the state religion? Retrieved January 21, 2014 from http://www.fergananews.com/articles/8020

Malashenko, A., Ilkhomov, A. (2014) ISIS and Central Asia: They frighten us, but we are not afraid? Retrieved October 17, 2014 from http://www.fergananews.com/articles/8283.

Malashenko, A. (2015) Does Islamic State Threaten Central Asia? https://iwpr.net/global-voices Accessed February 6, 2015

Musurmsnkulov, N. (2013). Mahalla - an important subject of self-government. ,351-353

Newskaz.ru (2015) Tajikistan strengthens border due to the concentration of Afghan militants in its borders. Retrieved January 16, 2015 from: http://newskaz.ru/world news/20150116/7458340.html

Nur.kz (2014) More than 300 Kazakhs are fighting on the side of the ISIS. Retrieved May 21, 2014from http://news.nur.kz/341050.html

Panfilova, V. (2015). Black banners of ISIS appeared at the borders of Turkmenistan. Nezavisimay Gazeta. Retrieved February 19, 2015 from http://www.ng.ru/cis/2015-02-19/1 igil.html

Report-IA (2015) Expert: ISIS regards Central Asia and the Caucasus as a priority zone of its interests. Retrieved February 5, 2015 from: http://report.az/ru/analitika/igil-central-naya-aziya-kavkaz-terror-geopolitika/

Rossiya (2015) In Turkmenistan since January there is a mobilization of reservists, writes "the Chronicle of Turkmenistan" (2015) Retrieved February 10, 2015 from: http://24th.ru/page/v-turkmenistane-navoinskuju-sluzhbu-prizyvajut-rezervistov

Sorbello, P. (2015). Islam and Central Asia: threat or myth? Retrieved March 25, 2015from http://www.inozpress.kg/news/view/id/43721

TASS Russian News Agency (2015). The Ministry of Internal Affairs of Tajikistan declared the concentration of large forces of Afghan militants on the border. Retrieved January 16, 2015 from http://tass.ru/mezhdunarodnaya-panorama/1701633

Uzbekistan news (2014) ISIS - not a religious organization. Retrieved October 13, 2014 from: http://nuz.uz/antiterror/3831-igil-ne-religioznaya-organizaciya.html

Yuldasheva, N. (2015) Fighters of the ISIS planned acts of terrorism during presidential elections in Uzbekistan. , 1128. 